University of Nebraska - Lincoln

DigitalCommons@University of Nebraska - Lincoln

Publications, Agencies and Staff of the U.S.

Department of Commerce

U.S. Department of Commerce

2011

\title{
The response of fish larvae to decadal changes in environmental forcing factors off the Oregon coast
}

Toby D. Auth

Oregon State University, toby.auth@noaa.gov

Richard D. Brodeur

NOAA Fisheries

Heather L. Soulen

Oregon State University

Lorenzo Ciannelli

Oregon State University

William T. Peterson

NOAA Fisheries

Follow this and additional works at: https://digitalcommons.unl.edu/usdeptcommercepub

Part of the Environmental Sciences Commons

Auth, Toby D.; Brodeur, Richard D.; Soulen, Heather L.; Ciannelli, Lorenzo; and Peterson, William T., "The response of fish larvae to decadal changes in environmental forcing factors off the Oregon coast" (2011). Publications, Agencies and Staff of the U.S. Department of Commerce. 227.

https://digitalcommons.unl.edu/usdeptcommercepub/227

This Article is brought to you for free and open access by the U.S. Department of Commerce at DigitalCommons@University of Nebraska - Lincoln. It has been accepted for inclusion in Publications, Agencies and Staff of the U.S. Department of Commerce by an authorized administrator of DigitalCommons@University of Nebraska - Lincoln. 


\section{The response of fish larvae to decadal changes in environmental forcing factors off the Oregon coast}

\author{
TOBY D. AUTH, ${ }^{1, *}$ RICHARD D. BRODEUR, ${ }^{2}$ \\ HEATHER L. SOULEN, ${ }^{1}$ LORENZO \\ CIANNELLI $^{3}$ AND WILLIAM T. PETERSON ${ }^{2}$ \\ ${ }^{1}$ Cooperative Institute for Marine Resources Studies, Oregon \\ State University, Hatfield Marine Science Center, 2030 Marine \\ Science Drive, Newport, OR 97365, USA \\ ${ }^{2}$ Northwest Fisheries Science Center, NOAA Fisheries, Hatfield \\ Marine Science Center, 2030 Marine Science Drive, Newport, \\ OR 97365, USA \\ ${ }^{3}$ College of Oceanic and Atmospheric Sciences, Oregon State \\ University, 104 COAS Administration Building, Corvallis, OR \\ 97331, USA
}

\begin{abstract}
We conducted a statistical analysis to characterize the influence of large-scale and local environmental factors on presence-absence, concentration, and assemblage structure of larval fish within the northern California Current (NCC) ecosystem, based on samples collected at two nearshore stations along the Newport Hydrographic line off the central Oregon coast. Data from 1996 to 2005 were compared with historical data from the 1970s and 1980s to evaluate pseudo-decadal, annual, and seasonal variability. Our results indicate that the most abundant taxa from 1996 to 2005 differ from those of earlier decades. Concentrations of the dominant taxa and total larvae were generally greater in the winter/spring than summer/fall season. Using generalized additive modeling, variations in presence-absence and concentration of taxa were compared to climate indices such as the Pacific Decadal Oscillation, Northern Oscillation Index, and the multivariate ENSO index and local environmental factors, such as upwelling, Ekman transport, and wind stress curl. Significant relationships were found for various combinations of environmental variables with lag periods ranging from 0 to 7 months. We found that the large-scale climate indices explained more of the variance in larval fish
\end{abstract}

*Correspondence. e-mail: toby.auth@noaa.gov

Received 5 January 2010

Revised version accepted 9 March 2011 concentration and diversity than did the more local factors. Our results indicate that readily available oceanographic and climate indices can explain variations in the dominant ichthyoplankton taxa in the NCC. However, variation in response among taxa to the environmental metrics suggests additional unknown factors not included in the analysis likely contributed to the observed distribution patterns and larval fish community structure in the NCC.

Key words: assemblage, California Current, distribution, environment, fish larvae, ichthyoplankton, North Pacific Ocean, Oregon, time series

\section{INTRODUCTION}

Variability in survival through the larval stage is believed to play an important role in determining subsequent recruitment success of marine fishes (Bradford, 1992; Houde, 1997, 2008). Larval-stage dynamics can be influenced by both regional and basin-wide environmental fluctuations (Hsieh et al., 2005; Boeing and Duffy-Anderson, 2008; Doyle et al., 2009). Fishery independent larval surveys can potentially enhance fishery management decisions through timely information on year-class survival and recruitment success (Fuiman and Werner, 2002).

Studies using long time series of survey data to document the response of ichthyoplankton to environmental changes are rare, primarily because long data sets are largely unavailable. Beaugrand et al. (2003) analyzed monthly data collected during 19581999 to show that Gadus morhua (Atlantic cod) recruitment in the North Sea was related to temperature-dependent larval survival. The National Marine Fisheries Service (NMFS) Southwest Fisheries Center's (SWFC) California Cooperative Oceanic Fisheries Investigation (CalCOFI) program has collected ichthyoplankton samples continuously from 1950 to the present in the southern California Current (SCC) region. These samples have been the basis for multiple studies relating ichthyoplankton distribution and community structure to environmental variables since Ahlstrom (1966) first documented the cyclical fluctuations in Sardinops sagax (Pacific sardine) and 
Engraulis mordax (northern anchovy) larval abundances in the SCC. More recently, Hsieh et al. (2005) examined long-term changes in the CalCOFI larval fish communities in relation to climate change and found that most oceanic but few coastal and coastaloceanic taxa were significantly related to environmental variables.

Several relatively short-term studies conducted in the northern California Current (NCC) have suggested that ichthyoplankton distribution and community structure vary in relation to changes in temperature and salinity (Auth and Brodeur, 2006; Parnel et al., 2008), timing and intensity of upwelling (Brodeur et al., 2006), pseudo-decadal (5-10-yr) environmental oscillations (e.g., El Niño, La Niña) (Brodeur et al., 1985; Doyle, 1995), and combinations of multiple environmental factors (Auth, 2008; Brodeur et al., 2008).

Insights into the factors that may influence ichthyoplankton community structure were derived from studies of copepod species composition in the NCC, another member of the plankton community. Analysis of the copepod species composition from the same samples we discuss in this manuscript has shown that copepod biomass is strongly correlated with both the Pacific Decadal Oscillation (PDO) and Multivariate ENSO Index (MEI). In addition, copepod species richness has increased by approximately $50 \%$ since the 1970s and 1980s (Hooff and Peterson, 2006), with the increased species richness due to greater numbers of warm-water subtropical species in both summer and winter. However, there have been no differences in copepod biomass over the period 1969-1973 as compared to the recent time series of 1996-2007, suggesting that the effects of local upwelling are not different between the 1970s and more recent years. Thus, the observations of increased biodiversity but constant copepod biomass lead us to suggest that there have been fundamental changes in the source waters that feed the NCC which have led to subtle changes in food chain structure in the region. Because of this result, we embarked upon the study presented here, to determine whether there were similar changes in the ichthyoplankton and, if so, the degree to which changes could be attributed to local versus large-scale environmental forcing.

The present study is the first in the NCC to use a long time series of data to examine the relationship between the concentration and community structure of larval fishes, and both regional and basin-wide environmental variables. We synthesized ichthyoplankton data from four studies collected from the same two nearshore stations off the central Oregon coast during 1971-2005, and examined seasonal and pseudo-decadal changes in larval concentration, community structure, diversity, and evenness. In addition, we incorporated environmental data collected from readily available sources into generalized additive models (GAMs) to determine the most important environmental factors relating to the trends in larval fish data. The purpose of this study is to support informing fisheries management of the influence of climate on stock structure by affecting recruitment success of larval life-history stages.

\section{METHODS}

\section{Sampling procedures}

Larval fish were collected from two stations (NH05: $124.17^{\circ} \mathrm{W}$; NH10: $124.29^{\circ} \mathrm{W}$ ) located 9 and $18 \mathrm{~km}$ off the central Oregon coast along the historically sampled Newport Hydrographic $(\mathrm{NH})$ line $\left(44.65^{\circ} \mathrm{N}\right)$ in 62 and $82 \mathrm{~m}$ of water, respectively (Fig. 1). A total of 350 biweekly-monthly samples were collected during four separate studies: 61 in January 1971 to August 1972 (Richardson and Pearcy, 1977), ten in November 1977 to June 1978 (NH05 only) (Laroche et al., 1982),

Figure 1. Map showing the location of the two stations sampled in the studies incorporated in this comparative study. Also shown are 200- and 500-m isobaths.

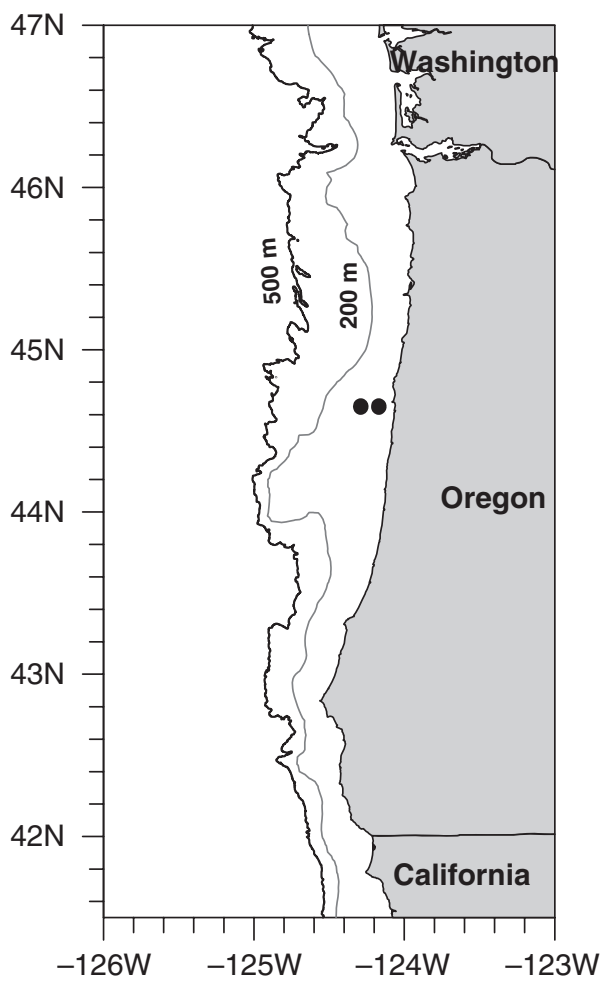


21 in April to September 1983 (Brodeur et al., 1985), and 258 in December 1996 to December 2005 (Brodeur et al., 2008). Collection methods varied slightly (Table 1) but generally consisted of 60-70-cm bongos with $200-571-\mu \mathrm{m}$ mesh nets and either TSK or General Oceanics flowmeters, fished obliquely from either $20 \mathrm{~m}$ depth or within $5 \mathrm{~m}$ of the bottom to the surface. Ichthyoplankton samples were preserved in a $10 \%$ buffered-formalin seawater solution at sea. Preserved samples were taken to the laboratory, where all fish larvae from each sample were sorted, enumerated, and identified to the lowest taxonomic level possible using a dissecting microscope. Most larval Osmerids (smelts), Sebastes spp. (rockfishes), Citharichthys spp. (sanddabs), and Liparis spp. (snailfishes) collected were not identifiable to species based on meristics and pigmentation patterns, so these taxa were analyzed at the family or generic level. In the northeast Pacific Ocean, seven species of Osmerids, two species of Citharichthys, 17 species of Liparis, and 65 species of Sebastes are known to occur (Matarese et al., 1989; Love et al., 2002).

\section{Data analyses}

Larval fish concentrations for each sample were expressed as the number of individuals per $1000 \mathrm{~m}^{3}$. Taxon diversity and evenness were calculated for each sample based on all identifiable larval fish taxa $(n=94)$. The Shannon-Wiener diversity index $\left(H^{\prime}\right)$ was used to measure larval diversity, where higher $H^{\prime}$ values denote greater diversity. Taxa evenness was assessed using Pielou's evenness index ( $\left.J^{\prime}\right)$, which ranges from 0 to 1 , with the maximum $J$ ' value indicating that all taxa are represented in the same relative concentrations. Both $H^{\prime}$ and J' were calculated according to the formulas of Shannon and Weaver (1949) and Krebs (1989). Samples with $n \leq 1$ taxon present were not included in the analyses because $H^{\prime}=0$ and $J^{\prime}$ could not be calculated. All diversity and evenness analyses were performed using PRIMER v. 5.2.9 statistical software (PRIMER-E, Plymouth, UK).

Previous studies (Richardson and Pearcy, 1977; Auth and Brodeur, 2006) had shown that ichthyoplankton from the two inshore stations on the $\mathrm{NH}$ line examined in this study were part of the nearshore fish assemblage, and statistical analyses revealed no significant differences in the dominant taxa between these stations (Brodeur et al., 2008). Thus, fish larvae were averaged from the two stations for subsequent analyses. Because samples were not always collected at the same intervals (e.g., weekly, biweekly, monthly) or at both stations on a given cruise, mean larval concentration, diversity, and evenness values from both

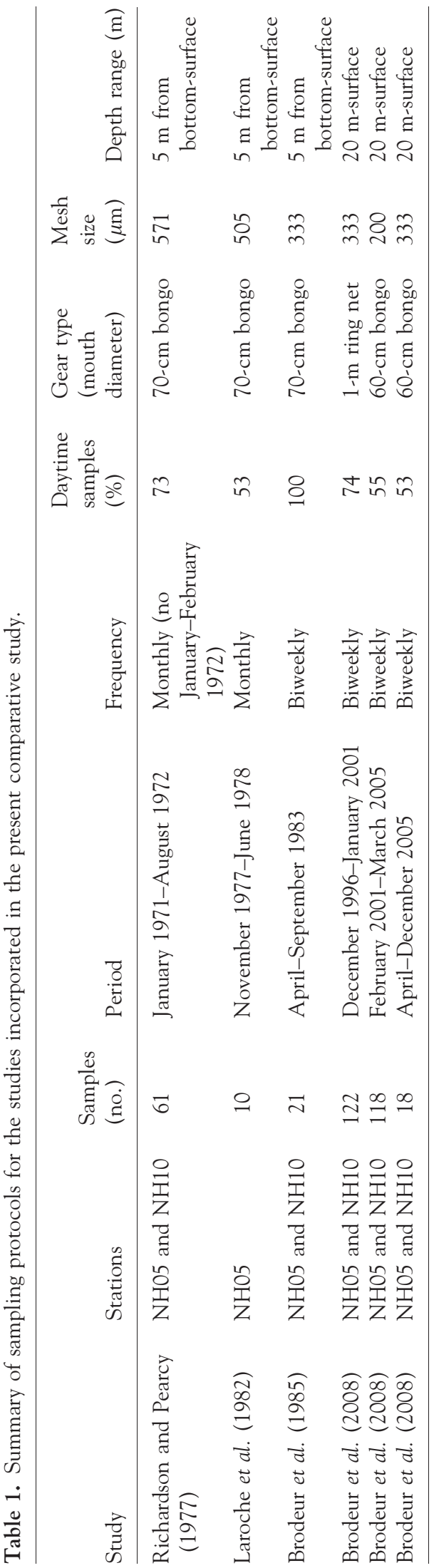

(c) 2011 Blackwell Publishing Ltd, Fish. Oceanogr., 20:4, 314-328. 
stations during each cruise were averaged for all cruises within each month. All data analyses were based on these monthly averaged data. To facilitate seasonal analyses, months were classified as either winter/spring (January to May) or summer/fall (June to December) based on results from the seasonal analysis of Brodeur et al. (2008). ANOVA and Tukey's multiple range test were applied to the $\log _{e}(n+0.1)$ transformed monthly larval concentration, diversity, and evenness values to test for significant differences between seasons. Only five dominant larval taxa had sufficient frequencies of occurrence and concentrations to allow for meaningful statistical analysis. Statistical significance was determined at $\alpha=0.05$. All ANOVA analyses were performed using JMP v. 5.1 statistical software (SAS Institute, Cary, NC, USA).

We used GAM analysis to explore the relationships between larval concentration and diversity metrics and basin- and regional-scale environmental variables. GAM is a nonlinear regression technique, where the relationships between the response variable and the forcing variables (covariates) are modeled with nonparametric smooth functions (Hastie and Tibshirani, 1990; Wood, 2004, 2006). When using GAM, it is unnecessary to specify the type of relationships between the forcing and response variables a priori because these are determined from the data. Specifically, given a response variable $y$ and a set of $m$ forcing variables $x$ (covariates), the relationship between the two is established by:

$$
y_{i}=\alpha+\sum_{j=1}^{m} g_{j}\left(x_{j i}\right)+e_{i}
$$

The $g_{j}$ are smooth non-parametric functions, typically natural cubic splines (Green and Silverman, 1994). 'Smooth' means that the function $g_{j}\left(x_{j i}\right)$ is continuous (no jumps), and it has continuous first and second derivatives (no abrupt change of the slope). In recent GAM applications, the degree of freedom (controlling smoothness versus roughness) for each smooth term can be simultaneously and objectively estimated by minimizing the generalized cross-validation (GCV), a measure of the 'leave-one-out' mean predictive square error (Green and Silverman, 1994). In this study the maximum number of degrees of freedom was set to be $\leq 4$. Depending on the nature of the data, GAMs are generalized to different distribution families, including normal and binomial. We applied GAM to the following dependent variables: concentration of dominant taxa, total larval concentration, and total larval diversity. Concentration of both total and dominant taxa was modeled assuming a normally distributed error (Gaussian family and iden- tity link) on $\log _{e}(n+1)$-transformed data excluding the zero catches, and using a binomial family (logit link) on presence-absence data. This two-step approach is commonly applied when the data set is characterized by an excess of zero catches, as was the case in the present study (Fox et al., 2000).

Prior to inclusion in the GAMs, potential independent environmental variables that may influence the distribution, abundance, and transport of coastal fish larvae were examined using nonparametric Spearman's rho correlations to eliminate variables that were significantly correlated with more than half of all the variables at the $\alpha=0.01$ level. As a result of the correlation analysis, Columbia River flow $\left(\mathrm{m}^{3} \mathrm{~s}^{-1}\right)$, sea-surface temperature $\left({ }^{\circ} \mathrm{C}\right)$, and northward Ekman transport $\left(\mathrm{kg} \mathrm{m}^{-1}\right)$ were excluded from the list of covariates included in the GAMs (Table 2).

Larval concentrations and presence-absences were compared to large-scale environmental variables (i.e., MEI, NOI, PDO; Table 2) with lags of 1, 2, 3, 5, and 7 months to account for delayed effects of changes in basin-wide water masses on larval concentrations. Regional variables (i.e., CWS, EET, UPW; Table 2) were not lagged as they were assumed to affect larval dynamics in real time (same month). To decide which covariates to retain in the final concentration models, we applied a backward strategy based on the minimization of the GCV, a measure of the model prediction error (Wood and Augustin, 2002; Wood, 2004). For presence-absence data, the selection was instead based on the unbiased risk estimator (UBRE) - an error index penalized for excessive nonlinear smoothers, analogous to the GCV. Specifically, covariates were all included in the model and eliminated one at a time until the GCV reached a minimum. The order in which covariates were excluded was based on the significance of their smooth-term effect (expressed by the P-value). Least-significant variables (i.e., those with the highest $P$-values) were eliminated first. This model selection strategy sometimes retains variables with $P$-values within the $>0.05-0.1$ range. This is normal, as the $P$-value of each smooth term is approximated (Wood, 2004, 2006). All GAMs were constructed in the R 2.3.1 programming environment using the gam function of the $m g c v$ package (The R Foundation for Statistical Computing, http://www.r-project.org).

\section{RESULTS}

\section{Environmental factors}

Basin-scale (i.e., MEI, NOI, PDO) and regional (i.e., CWS, EET, UPW) environmental indices and vari- 
Table 2. Abbreviations, descriptions, and sources of the basin- and regional-scale environmental variables used in the general additive modeling (GAM).

\begin{tabular}{|c|c|}
\hline Abbreviation & Description and source \\
\hline \multicolumn{2}{|l|}{ Basin scale } \\
\hline MEI & $\begin{array}{l}\text { Multivariate El Nino-Southern Oscillation Index. From the NOAA Earth System Research Laboratory } \\
\text { website: http://www.cdc.noaa.gov/ENSO/enso.mei_index.html. }\end{array}$ \\
\hline $\mathrm{NOI}$ & $\begin{array}{l}\text { Northern Oscillation Index. From the NOAA Environmental Research Division website: http://www. } \\
\text { pfeg.noaa.gov:16080/products/PFEL/modeled/indices/NOIx/noix.html. }\end{array}$ \\
\hline PDO & $\begin{array}{l}\text { Pacific Decadal Oscillation. From the University of Washington (Nathan Mantua administrator) website: } \\
\text { http://jisao.washington.edu/pdo/. }\end{array}$ \\
\hline \multicolumn{2}{|l|}{ Regional scale } \\
\hline CWS & $\begin{array}{l}\text { Curl of the wind stress }\left(10^{6} \mathrm{~m}^{-2} \mathrm{~kg} \mathrm{~s}^{-2}\right) \text { from a } 1 \times 1^{\circ} \text { square area centered at } 44.5^{\circ} \mathrm{N}, 124.5^{\circ} \mathrm{W} \text {. From } \\
\text { the NOAA Southwest Fisheries Science Center Environmental Research Division live access server } \\
\text { website: http://www.pfeg.noaa.gov/products/las.html. }\end{array}$ \\
\hline EET & $\begin{array}{l}\text { Eastward Ekman transport }\left(\mathrm{kg} \mathrm{m}^{-1}\right) \text { from a } 1 \times 1^{\circ} \text { square area centered at } 44.5^{\circ} \mathrm{N}, 124.5^{\circ} \mathrm{W} \text {. From the } \\
\text { NOAA Southwest Fisheries Science Center Environmental Research Division live access server } \\
\text { website: http://www.pfeg.noaa.gov/products/las.html. }\end{array}$ \\
\hline UPW & $\begin{array}{l}\text { Upwelling Index for } 45^{\circ} \mathrm{N}, 125^{\circ} \mathrm{W} \text {. From the NOAA Southwest Fisheries Science Center Environmental } \\
\text { Research Division live access server website: http://www.pfeg.noaa.gov/products/las.html. }\end{array}$ \\
\hline
\end{tabular}

ables varied seasonally, annually, and pseudodecadally throughout the study (Fig. 2a-c). From 1970 through 2005, the NCC experienced fluctuating cool and warm periods, marked by warm, strong El Niño events in winter 1972-1973, 1983, 1987, 1992, 1997-1998, and weak El Niño conditions in 2003-2005 (Fig. 2a). For the collection periods in this study, 1971-1972 were relatively cool years, 1977-1978 warm, 1983 warm, 1996-1998 warm, 1999-2002 cool, and 2003-2005 warm.

\section{Larval concentrations and assemblages}

A total of 19912 fish larvae comprising 102 taxa from 29 families were collected between 1971 and 2005. Six families accounted for $87.1 \%$ of the total larval concentration: Osmeridae (34.7\%), Pleuronectidae (28.9\%), Ammodytidae (8.5\%), Scorpaenidae (6.5\%), Cottidae (4.4\%), and Paralichthyidae (4.1\%). Within these families, five taxa had the greatest numerical abundance: Osmeridae, Parophrys vetulus, Ammodytes hexapterus, Sebastes spp., and Isopsetta isolepis (Tables 3 and 4). Although $P$. vetulus larvae were consistently among the dominant taxa throughout the study period, the remaining larval assemblage varied (Fig. 3). The larval assemblage was dominated by Osmerids and I. isolepis in 1971-1972, Osmerids, Sebastes spp., Psettichthys melanostictus, and I. isolepis in 1977-1978, E. mordax and Sebastes spp. during the spring and summer sampling in 1983, Citharichthys spp. and A. hexapterus in 1996-1998, A. hexapterus, Citharichthys spp., I. isolepis, and Osmerids in 1999-2002, and E. mordax, Sebastes spp., and Citharichthys spp. in 2003 2005.
Larval concentration varied annually and seasonally throughout the study periods. Concentrations of total larvae increased steadily from low in 19711972, to moderate in 1977-1978, to high in 1983, and increased dramatically from low in 1996-1999 to high in 2000-2005 (Fig. 2d). Seasonal concentrations of all five dominant taxa and total larvae were higher in the winter/spring than in the summer/fall (Table 5).

\section{Diversity and evenness}

Larval diversity and evenness varied annually and seasonally throughout the study (Fig. 2e). Diversity was highest in 1971-1973, moderate in 1977-1978, 1983, and 1997-1999, and decreased from 2000 to 2005. Evenness was moderate in the early years of the study, and showed a generally increasing trend from 1996 to 2005. Seasonal diversity was significantly higher in winter/spring than summer/fall $(P<0.05)$. Seasonal evenness varied interannually, but no significant differences were found between winter/ spring and summer/fall values for the entire study $(P>0.05)$.

\section{GAM analyses}

General additive modeling revealed best-fit models and significant $(P<0.05)$ environmental variables with various time lags for the five most abundant and total larval fish for both the concentration (Table 6, Fig. 4) and presence-absence (Table 7, Fig. 5) analyses, except in the case of the presence-absence model for total larval concentration. In general, the largescale climate indices explained more of the variance in 
Figure 2. Time series of nine environmental and biological variables analyzed in this study. Shown are the seasonally-averaged (winter/spring [on tick marks]: January to May; summer/fall [between tick marks]: June-December) values for the (a) Multivariate El Niño-Southern Oscillation Index (MEI) and Pacific Decadal Oscillation (PDO), (b) Northern Oscillation Index (NOI) and Upwelling Index (UPW) for $45^{\circ} \mathrm{N}, 125^{\circ} \mathrm{W}$, (c) eastward Ekman transport (EET) $\left(\mathrm{kg} \mathrm{m}^{-1}\right)$ and curl of the wind stress (CWS) $\left(10^{6} \mathrm{~m}^{-2} \mathrm{~kg} \mathrm{~s}^{-2}\right)$ both from a $1 \times 1^{\circ}$ square area centered at $44.5^{\circ} \mathrm{N}, 124.5^{\circ} \mathrm{W}$, (d) total mean larval concentration (no. $\left.1000 \mathrm{~m}^{-3}\right)$, and $(\mathrm{e})$ mean larval Shannon-Wiener diversity $\left(H^{\prime}\right)$ and Pielou's evenness indices $\left(J^{\prime}\right)$. In panels d and e, time periods without bars or data points indicate periods when no data was collected.

(a)

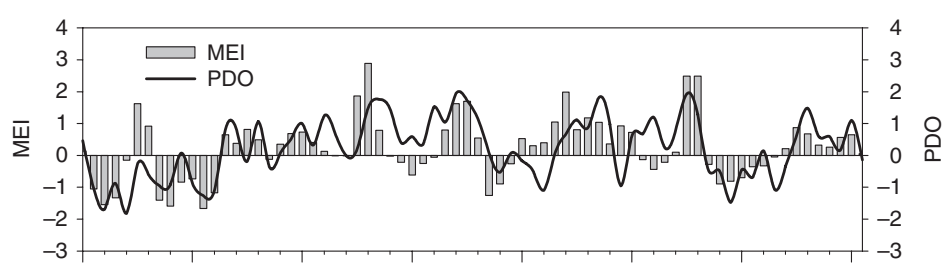

(b)

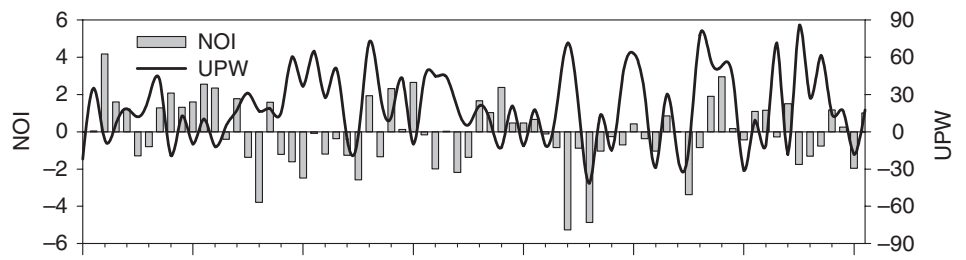

(c)

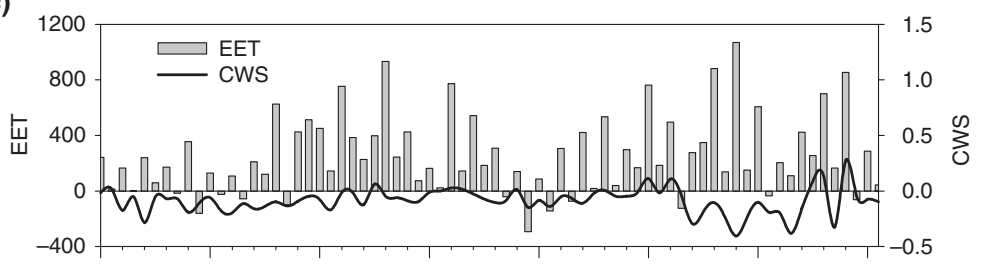

(d)

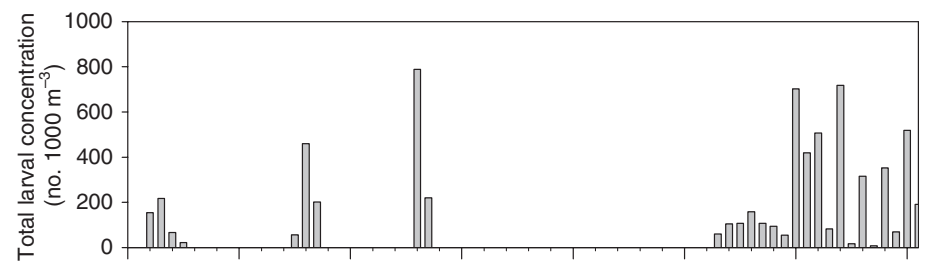

(e)

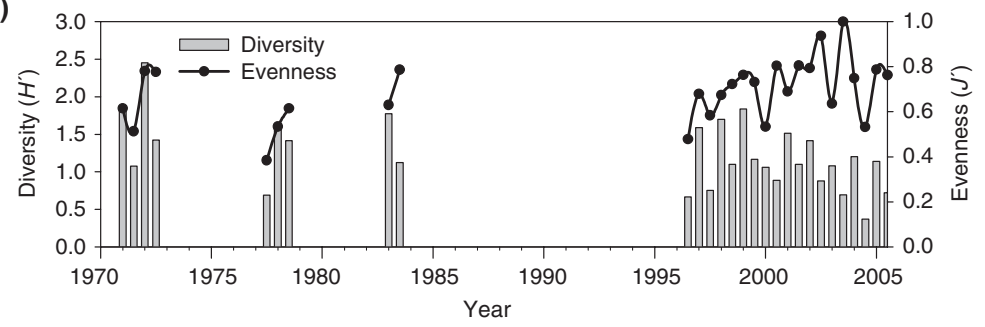

overall larval fish concentration and diversity, as well as that of the dominant taxa, than did the more local environmental factors.

The GAM analysis suggested that larval diversity was greatest when it lagged the NOI by 2 months and the NOI was either highly positive or negative and CWS was near zero. Total larval concentration decreased when it lagged the NOI by 5 months and the NOI increased, and was lowest when UPW was marginally positive $(\mathrm{UPW}=60)$. 
Table 3. Life history information for the five dominant larval fish taxa collected off the Oregon coast during this study and incorporated into the GAMs (Auth, 2009; Doyle et al., 2009; Houde, 1989; Laidig et al., 2004; Laroche et al., 1982; Matarese et al., 1989; Richardson et al., 1980). ? = no data or incomplete information.

\begin{tabular}{|c|c|c|c|c|c|c|}
\hline Taxon & $\begin{array}{l}\text { Peak larval } \\
\text { abundance } \\
\text { (season) }\end{array}$ & $\begin{array}{l}\text { Spawning } \\
\text { location }\end{array}$ & $\begin{array}{l}\text { Larval } \\
\text { habitat }\end{array}$ & $\begin{array}{l}\text { Length at } \\
\text { hatching } \\
(\mathrm{mm})\end{array}$ & $\begin{array}{l}\text { Length at } \\
\text { transformation } \\
(\mathrm{mm})\end{array}$ & $\begin{array}{l}\text { Larval stage } \\
\text { durration } \\
\text { (day) }\end{array}$ \\
\hline Ammodytes hexapterus & March-May & Intertidal & Coastal/shelf & $6-7$ & $16-31$ & $46-550 *$ \\
\hline Isopsetta isolepis & February-May & Coastal & Coastal/shelf & $2.7-2.9$ & 21 & $50-120$ \\
\hline Osmeridae & January-June & Gravel beaches & Coastal/shelf & $3-7$ & $50-80$ & $\sim 150$ \\
\hline Parophrys vetulus & January-March & Coastal/shelf & Coastal/shelf & $2.7-2.9$ & $18-22$ & $50-120$ \\
\hline Sebastes spp. & $\begin{array}{l}\text { April (?)- } \\
\text { November (?) }\end{array}$ & Upper slope (?) & $\begin{array}{l}\text { Coastal/shelf/ } \\
\text { offshore }\end{array}$ & $3.8-7.5^{\dagger}$ & $15-20$ & $\sim 80^{\ddagger}$ \\
\hline
\end{tabular}

*Larval stage duration reported for A. americanus.

†Length at which Sebastes spp. larvae are extruded.

Larval stage duration reported for Sebastes wilsoni.

Table 4. Composition, number, percent of total number, and monthly-averaged frequency of occurrence and mean concentration for the eight dominant larval fish taxa collected off the Oregon coast during this study.

\begin{tabular}{|c|c|c|c|c|c|}
\hline Taxon & Common name & $\begin{array}{l}\text { Overall } \\
\text { total no. }\end{array}$ & $\begin{array}{l}\% \text { of } \\
\text { total }\end{array}$ & $\begin{array}{l}\text { Frequency } \\
\text { occurrence }\end{array}$ & $\begin{array}{l}\text { Mean } \\
\text { concentration } \\
\left(\text { no. } 1000 \mathrm{~m}^{-3}\right)\end{array}$ \\
\hline Osmeridae & Smelts & 6905 & 35.13 & 0.33 & 20.65 \\
\hline Parophrys vetulus & English sole & 3199 & 16.27 & 0.42 & 58.94 \\
\hline Ammodytes hexapterus & Pacific sand lance & 1696 & 8.63 & 0.19 & 27.12 \\
\hline Sebastes spp. & Rockfishes & 1291 & 6.57 & 0.50 & 18.25 \\
\hline Isopsetta isolepis & Butter sole & 976 & 4.97 & 0.30 & 11.03 \\
\hline Psettichthys melanostictus & Sand sole & 822 & 4.18 & 0.47 & 8.45 \\
\hline $\begin{array}{l}\text { Citharichthys sordidus or } \\
\text { stigmaeus }\end{array}$ & $\begin{array}{l}\text { Pacific or speckled } \\
\text { sanddab }\end{array}$ & 820 & 4.17 & 0.32 & 26.86 \\
\hline Engraulis mordax & Northern anchovy & 592 & 3.01 & 0.19 & 20.13 \\
\hline
\end{tabular}

Concentration of A. hexapterus larvae decreased as UPW increased, and was lowest when it lagged the PDO by 5 months and the PDO was near zero. Presence of A. hexapterus larvae in the ichthyoplankton decreased as CWS increased and EET decreased, and was greatest when presence lagged the PDO by 1 month and when the PDO was highly negative $(\mathrm{PDO}<-1)$, but otherwise presence-absence was mostly unaffected by changes in the PDO.

Concentration of I. isolepis was significantly influenced by the NOI when concentrations were lagged by 2 months reaching local maxima when the NOI was either highly negative $(\mathrm{NOI}<-5)$ or intermediately positive $(3<\mathrm{NOI}<6)$, while presence of $I$. isolepis larvae decreased when values were lagged by 3 months against the PDO and the PDO increased. There were no significant relationships with UPW, CWS or EET.

Osmerid presence in the ichthyoplankton, when lagged by 2 months, was similarly inversely related to the PDO. Concentration of osmerid larvae was positively and linearly related to the NOI when lagged by 3 months, and nonlinearly related to the MEI when lagged by 3 months, with highest concentrations at either highly negative (MEI $<-1.5$ ) or intermediately positive $(\mathrm{MEI}=1)$ values.

Larval $P$. vetulus presence and concentration were significantly influenced by the greatest number of environmental indices and factors. Presence of $P$. vetulus larvae in the ichthyoplankton was greatest as EET increased, when it lagged the PDO by 7 months and the PDO was approximately even $(\mathrm{PDO}=0)$, when it lagged the MEI by 7 months and the MEI was either highly negative $(\mathrm{MEI}<-1)$ or highly positive (MEI $>2$ ), and when it lagged the $\mathrm{NOI}$ by 7 months and the NOI was either even $(\mathrm{NOI}=0)$ or highly positive $(\mathrm{NOI}>10)$. Concentration of $P$. vetulus larvae was least at low values of CWS, intermediate values of UPW 
Figure 3. Proportional contributions of the mean concentrations (no. $1000 \mathrm{~m}^{-3}$ ) of the eight most dominant and remaining ('other') larval fish taxa to the total mean larval concentrations found during six time periods examined in this study.

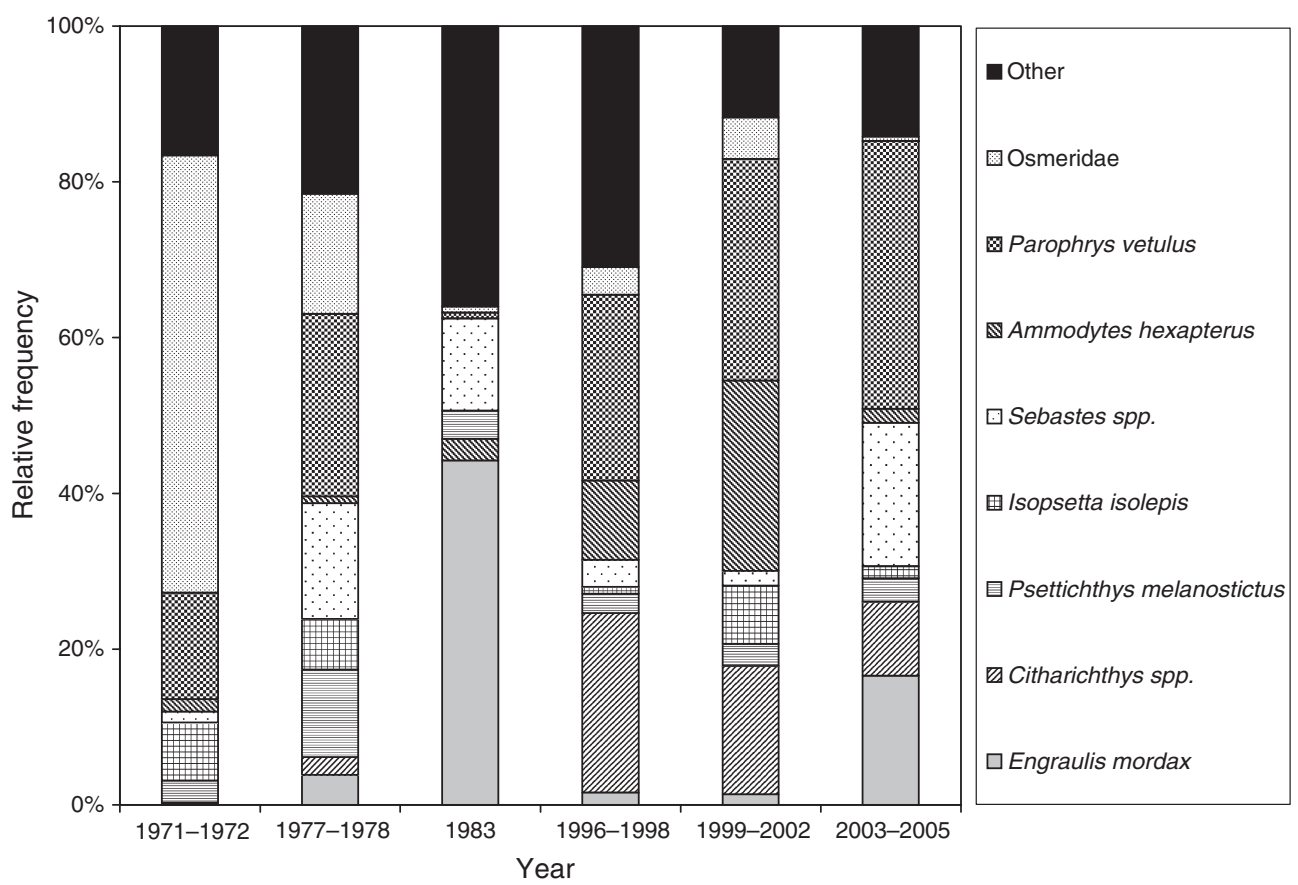

Table 5. Seasonal (winter/spring: January to May; summer/fall: June to December) mean concentrations (no. $1000 \mathrm{~m}^{-3}$ ) of dominant and total larval fish taxa collected off the Oregon coast during this study (1 SE in parentheses). For between-season comparisons of each taxon and total larvae, different superscripts indicate significant differences (ANOVA $P<0.05$ ).

\begin{tabular}{lcc}
\hline & \multicolumn{2}{c}{ Mean concentration } \\
\cline { 2 - 3 } Taxon & Winter/spring & Summer/fall \\
\hline Ammodytes hexapterus & $65.40(45.33)^{\mathrm{a}}$ & $0.08(0.08)^{\mathrm{b}}$ \\
Isopsetta isolepis & $25.16(16.32)^{\mathrm{a}}$ & $1.05(0.50)^{\mathrm{b}}$ \\
Osmeridae & $25.65(11.13)$ & $17.11(14.73)$ \\
Parophrys vetulus & $111.11(33.23)^{\mathrm{a}}$ & $22.06(12.23)^{\mathrm{b}}$ \\
Sebastes spp. & $37.72(21.56)^{\mathrm{a}}$ & $4.50(2.52)^{\mathrm{b}}$ \\
Total larvae & $369.76(76.78)^{\mathrm{a}}$ & $133.68(36.11)^{\mathrm{b}}$ \\
\hline
\end{tabular}

$(25<$ UPW < 125), and when it lagged the MEI by 5 months and the MEI was low $(\mathrm{MEI}<-1)$.

Concentration of Sebastes spp. larvae increased as EET increased, when it lagged the MEI by 7 months and the MEI increased, and when it lagged the PDO by 7 months and the PDO was even $(\mathrm{PDO}=0)$. Presence of Sebastes spp. larvae in the ichthyoplankton was least at low values of EET and when it lagged both the PDO and NOI by 2 months and both indices were approximately zero. These results suggest that each taxon responds differently to environmental forcing, as no single variable appeared in all of the GAM models.

\section{DISCUSSION}

Most variability in the NCC system is manifested in the form of interannual events and multidecadal climate regimes shifting between high and low production states (Peterson and Schwing, 2003; Schwing et al., 2009). Major processes affecting regional variability include: (i) changes in local wind forcing, resulting in variations in coastal upwelling and offshore Ekman pumping, (ii) changes in the transport of the California Current and California Undercurrent, (iii) changes in source water properties, (iv) volume and timing of freshwater input, (v) remote forcing via atmospheric and oceanic teleconnections, often associated with El Niño events or changes in the PDO, and (vi) heating of the upper ocean by global warming (Schwing et al., 2009).

The NCC ecosystem has undergone dramatic changes in the period encompassed by this study, including at least two regime shifts $(1976,1999)$, two of the strongest El Niños ever recorded (1982-1983 and 1997-1998), a strong La Niña (1999), a year with pronounced subarctic water influence (2002), anomalous upwelling conditions (2005), and the advent of a major hypoxic zone in coastal waters (2002 and other 


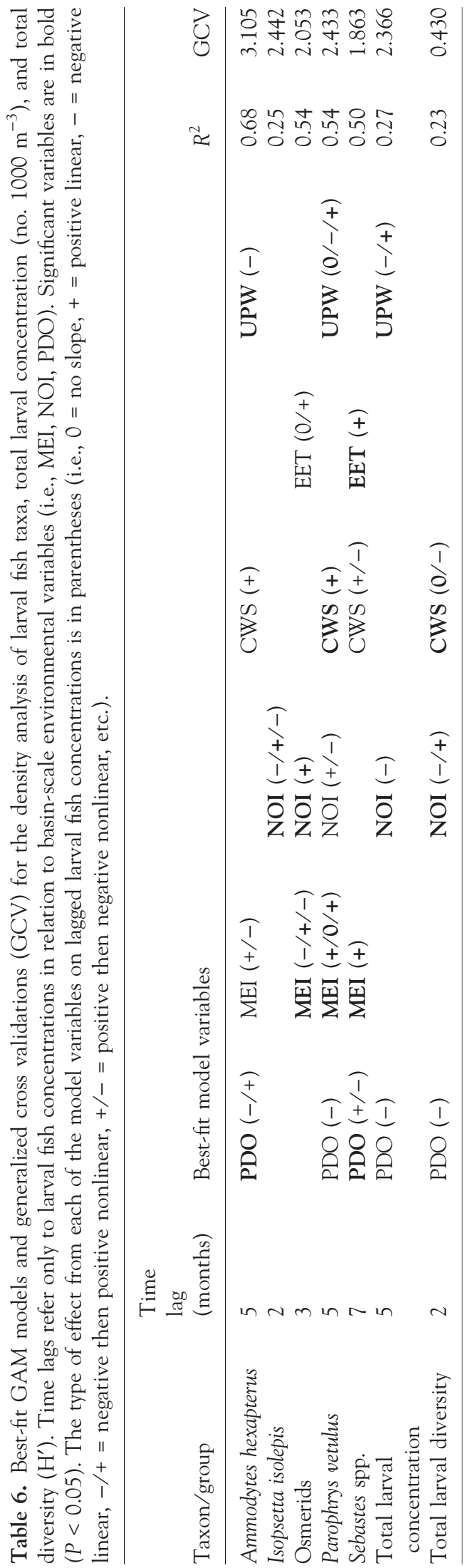

years) (Pearcy and Schoener, 1987; Peterson and Schwing, 2003; Wheeler et al., 2003; Barth et al., 2007; Huyer et al., 2007; Chan et al., 2008). These conditions led to major changes in adult (Pearcy and Schoener, 1987; Pearcy, 2002; Brodeur et al., 2005, 2006; Keller et al., 2010) and larval fish communities in the NCC region (Brodeur et al., 1985, 2006; Doyle, 1995). Differences in larval fish concentrations between years at a particular location may also be due to changes in spawning stock biomass and spawning location, reproductive output, differential egg and larval survival, and changes in cross- or along-shelf currents that may advect larvae to different areas.

Variability in sampling strategy between the different studies incorporated into the present study could also contribute to observed differences in larval concentrations. For instance, the mesh size of the nets used to collect samples in 1971-1972 (571 $\mu \mathrm{m})$ was slightly larger than that used in 1977-1978 (505 $\mu \mathrm{m})$ and approximately twice as large as that used in 1983 and 1996-2005 (200-333 $\mu \mathrm{m})$. This may have resulted in greater extrusion of small, slender larvae in the 1971-1972 collections, which could have contributed to the reduced concentrations of larvae found during this period relative to later years. However, Boeing and Duffy-Anderson (2008) found no significant differences in ichthyoplankton catch rates between paired 333- and 505- $\mu \mathrm{m}$ meshed nets deployed on the same bongo frame. In addition, the proportion of samples collected during the day versus night varied between the sampling periods. Concentrations of fish larvae collected in day samples have been found to be less than those reported from night samples from the same location, possibly due to net avoidance by larvae during the day (Auth et al., 2007). In the present study, higher concentrations of larvae were found in 1977-1978 and 2000-2005, where 53 and $54 \%$, respectively, of the samples were collected during the day, than in 1971-1972 and 1996-1999, where 73 and 95\%, respectively, of the samples were collected during the day. However, all of the samples in 1983 were collected during the day, and relatively high concentrations of larvae were still found. In addition, as different larval taxa exhibit different (or a lack of) diel vertical migration strategies (Auth et al., 2007) and no documented correction factors exist in the published literature for day-versusnight ichthyoplankton abundance estimates for each of the dominant taxa, we believe that there would have been undue bias associated with implementing an unproven diel correction factor per taxa prior to analyzing the data. Also, there was a concern that the variability in sampling depths (whole water column in 
Figure 4. Fitted lines (solid) and 95\% confidence intervals (dotted) for the additive effects of significant environmental variables on larval fish concentrations (no. $1000 \mathrm{~m}^{-3}$ ) from the best-fit GAM models. Time lags refer only to larval fish concentrations in relation to basin-scale environmental variables (i.e., MEI, NOI, PDO).

Ammodytes hexapterus (5-month lagged)
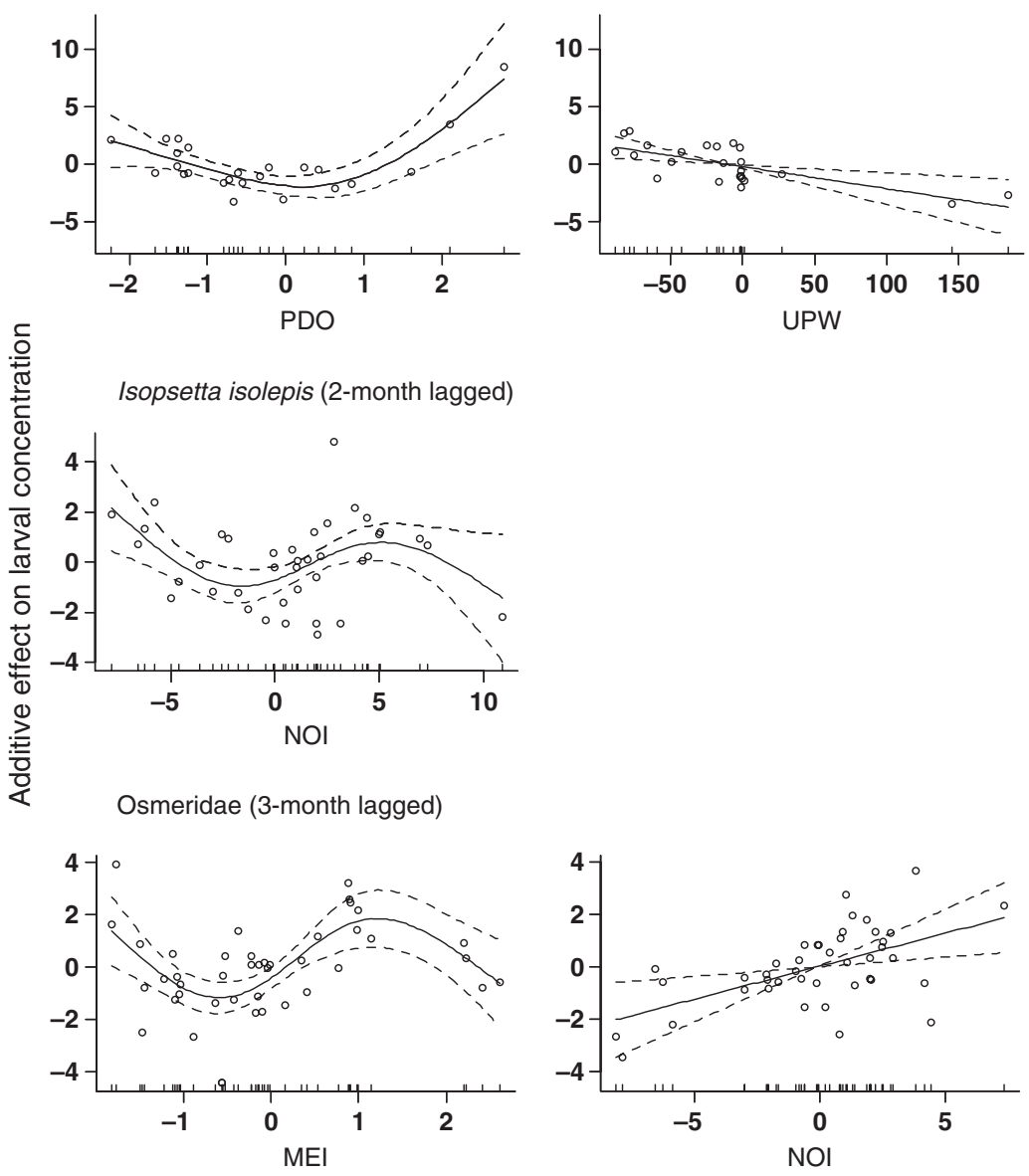

January 1971 to August 1972, November 1977 to June 1978, and April to September 1983; $20 \mathrm{~m}$ to surface in December 1996 to December 2005) may have biased comparative larval abundance estimates between study periods. However, Auth and Brodeur (2006) found that $92 \%$ of total fish larvae along the NH line in 2000 and 2002 were concentrated in the upper $20 \mathrm{~m}$ of the water column, so we believe that the majority of the larvae in the water column were collected in the shallower tows. Despite the myriad sources of variability inherent in sampling and life history characteristics, it has been shown that many of the dominant larval taxa off Oregon are indicators of the prevailing ocean conditions occurring in this region (Brodeur et al., 2008).

The situation where the different ichthyoplankton taxa showed differing responses to the environmental variables examined or were affected by different suites of variables may be explained by the varied repro-

ductive strategies represented. Most fish species spawn in the California Current in winter and spring, presumably to reduce offshore transport (Parrish et al., 1981), as is the case with A. hexapterus, some Sebastes spp., P. melanostictus, and I. isolepis in this study (Matarese et al., 1989). However, E. mordax spawn almost exclusively during the summer, while taxa such as Osmerids, other Sebastes spp., Citharichthys spp., and $P$. vetulus may have multiple spawning periods and are present in the plankton over much of the year, particularly from fall to spring (Brodeur et al., 2008; Parnel et al., 2008). This may be a factor affecting our results as the sampling during 1977-1978 occurred primarily during the winter and the sampling during 1983 occurred mainly in the summer (April to September), so many important larvae could have been missed due to timing of our sampling. Moreover, some species lay demersal adhesive eggs (Osmerids and A. hexapterus) and others have no external egg stage (C) 2011 Blackwell Publishing Ltd, Fish. Oceanogr., 20:4, 314-328. 
Figure 4. (Continued).
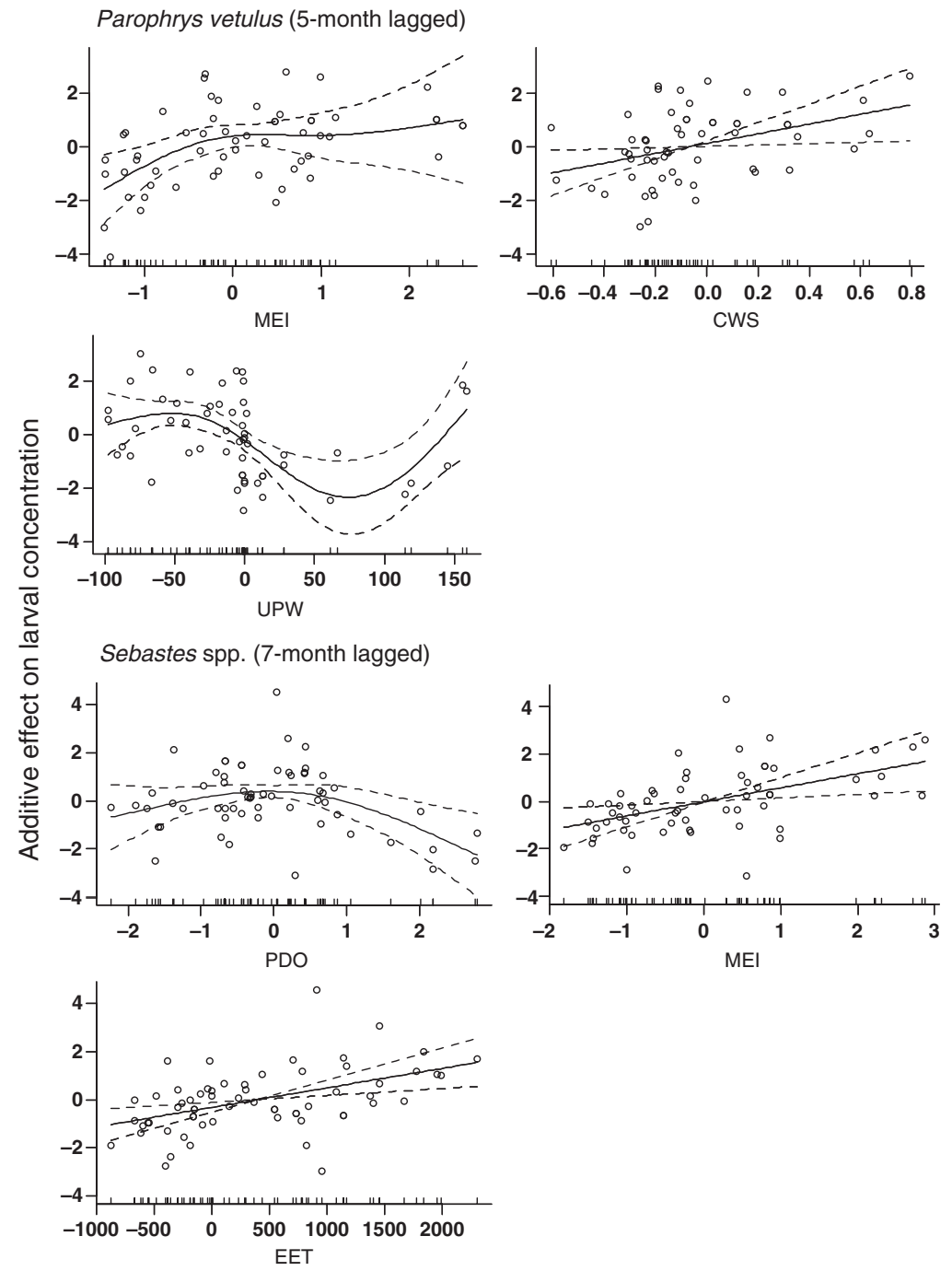

Total larval concentration (5-month lagged)
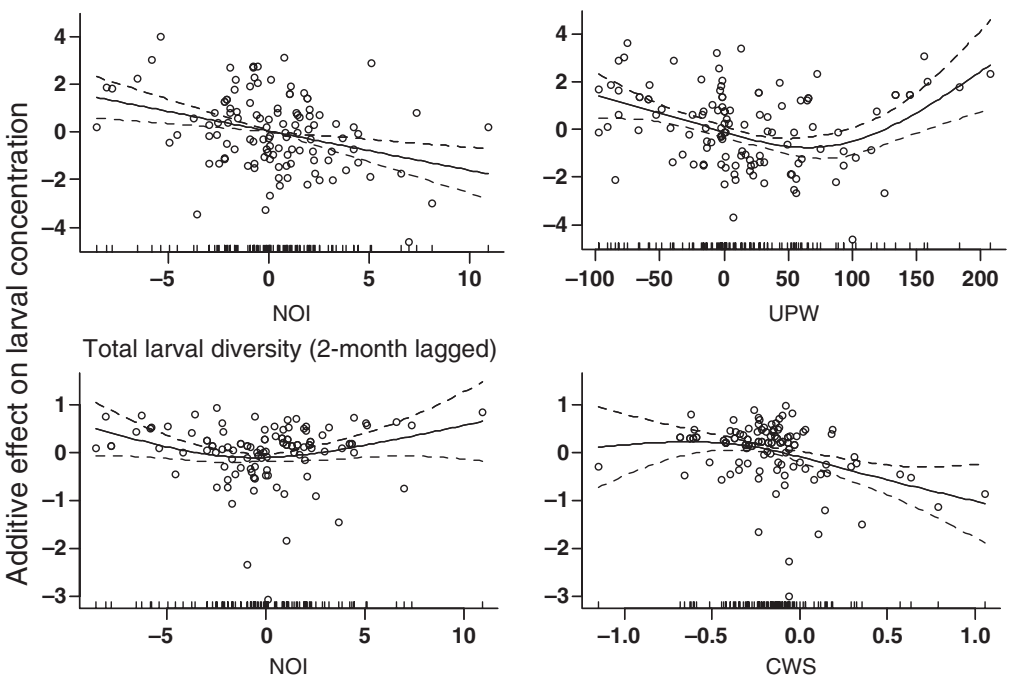

(c) 2011 Blackwell Publishing Ltd, Fish. Oceanogr., 20:4, 314-328. 
Table 7. Best-fit GAM models and unbiased risk estimators (UBRE) for the presence-absence analysis of larval fish taxa and total larval concentration (no. $1000 \mathrm{~m}^{-3}$ ). Time lags refer only to larval fish presence in relation to basin-scale environmental variables (i.e., MEI, NOI, PDO). Significant variables are in bold $(P<0.05)$. The type of effect from each of the model variables on lagged larval fish presence is in parentheses (i.e., $0=$ no slope, $+=$ positive linear, $-=$ negative linear, $-/+=$ negative then positive nonlinear, $+/-=$ positive then negative nonlinear, etc.).

\begin{tabular}{|c|c|c|c|c|c|c|c|c|c|}
\hline Taxon/group & $\begin{array}{l}\text { Time } \\
\text { lag } \\
\text { (months) }\end{array}$ & Best-fit model & variables & & & & & $R^{2}$ & UBRE \\
\hline Ammodytes hexapterus & 1 & $\operatorname{PDO}(-/ 0)$ & & $\mathrm{NOI}(0 /-/+)$ & CWS (-) & $\operatorname{EET}(+)$ & & 0.39 & 0.124 \\
\hline Isopsetta isolepis & 3 & PDO (-) & & & CWS $(+/-)$ & & & 0.20 & 0.184 \\
\hline Osmerids & 2 & PDO (- & $\operatorname{MEI}(+)$ & NOI $(-/+)$ & CWS $(0 /-)$ & EET (-) & $\begin{array}{l}\text { UPW } \\
(0 /-/+)\end{array}$ & 0.25 & 0.269 \\
\hline Parophrys vetulus & 7 & PDO $(+/-)$ & $\operatorname{MEI}(-/+)$ & NOI $(+/-/+)$ & & $\operatorname{EET}(+)$ & UPW (-) & 0.41 & 0.066 \\
\hline Sebastes spp. & 2 & PDO $(-/+)$ & & NOI $(-/+)$ & & $\operatorname{EET}(+)$ & & 0.29 & 0.086 \\
\hline $\begin{array}{l}\text { Total larval } \\
\text { concentration }\end{array}$ & 3 & $\mathrm{NOI}(-/+)$ & & & & EET (0) & & 0.22 & -0.493 \\
\hline
\end{tabular}

(Sebastes spp.), resulting in a shorter period for factors such as transport and predation to have an effect on survival.

In our study, we showed that when larval data lagged the large-scale climate indices by several months, the large-scale indicators, particularly the
PDO, explained more of the variance in larval abundance patterns than the regional or local indices. The primacy of large-scale over local forcing factors has been elucidated in a number of climate-ecological studies (see review by Stenseth et al., 2003). In a study similar to ours in the Gulf of Alaska, Doyle et al.

Figure 5. Fitted lines (solid) and 95\% confidence intervals (dotted) for the additive effects of significant environmental variables on larval fish presence from the best-fit GAM models. Time lags refer only to larval fish concentrations in relation to basin-scale environmental variables (i.e., MEI, NOI, PDO).

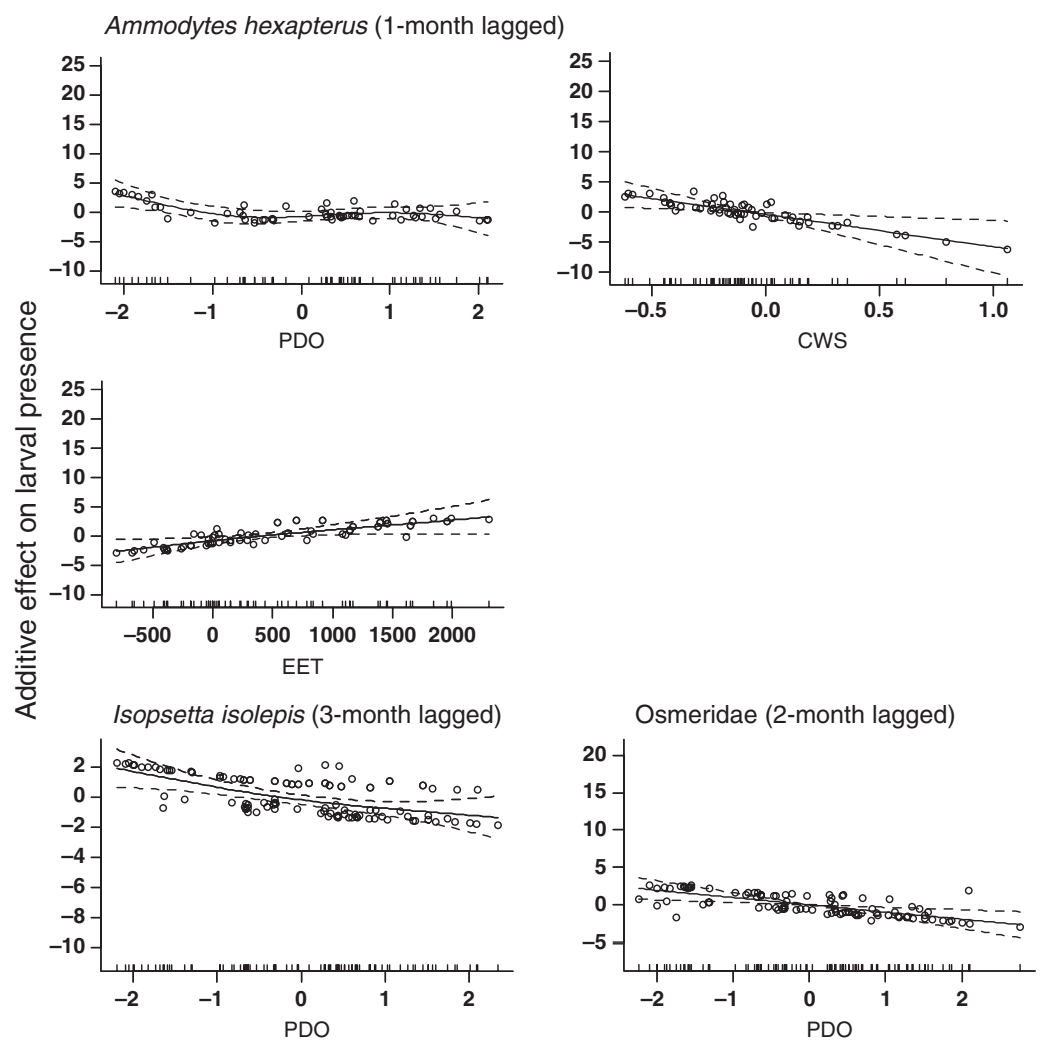

(C) 2011 Blackwell Publishing Ltd, Fish. Oceanogr., 20:4, 314-328. 
Figure 5. (Continued).
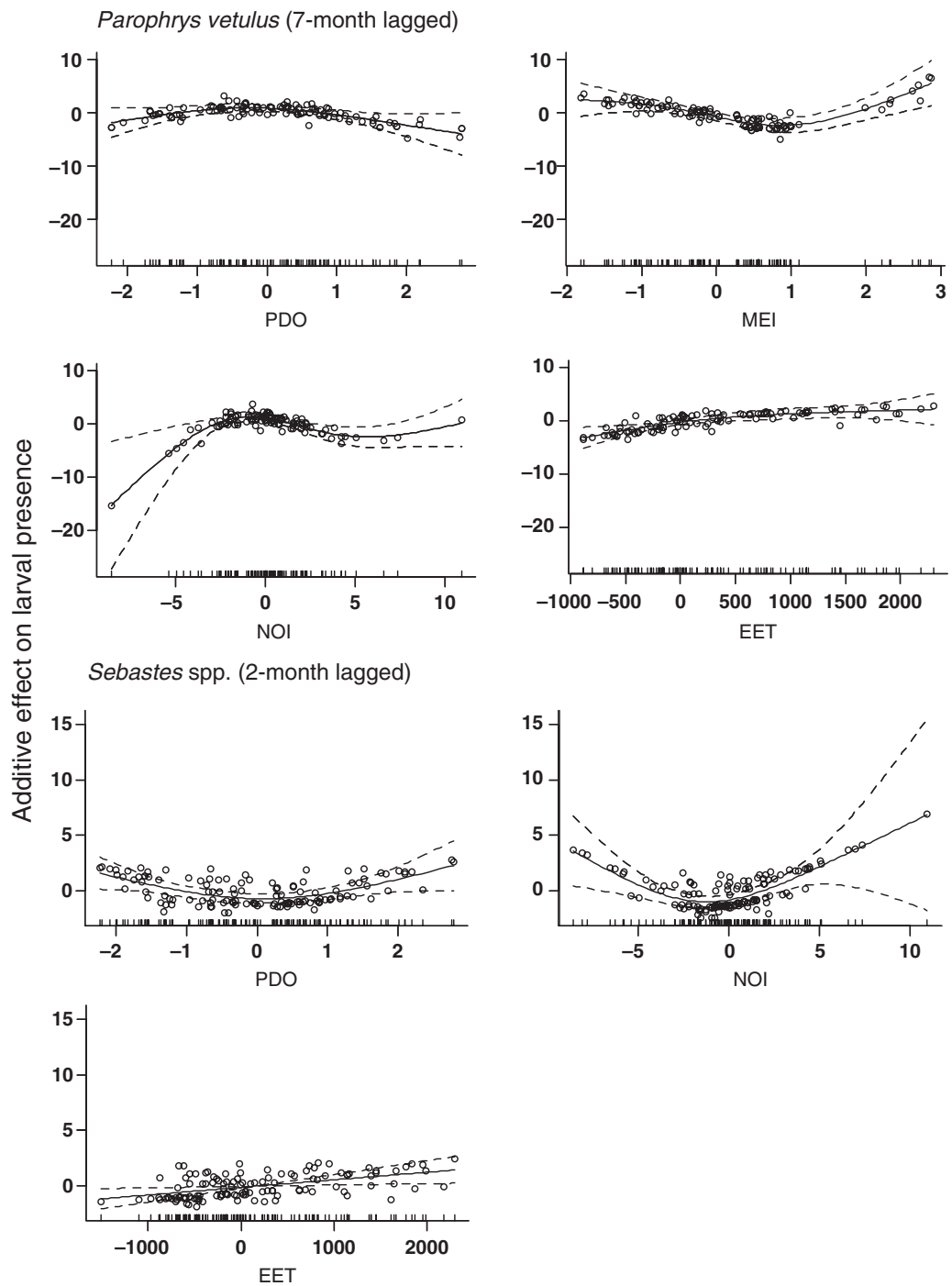

(2009) found both large-scale atmospheric forcing such as the East Pacific-North Pacific teleconnection index and PDO can be important for some larval fish species, whereas others are affected by more local factors such as alongshore transport, freshwater input, and sea surface temperature. Doyle et al. (2009) also used GAMs to determine which factors are most important but, in contrast to their methodology, we included both regional and local variables in the same models to elucidate the relative importance of the forcing factors similar to that done by Hooff and Peterson (2006). The relationships between larval abundance and the environment can be complex, with variability in larval abundance attributed to spatial variation, seasonality, non-stationarity through time, and likely non-linearity in physical forcing (Stenseth et al., 2003).

Our result that each fish taxon responds differently to environmental forcing and with different time lags is in contrast to results of a similar analysis of the copepod species abundance data from the same cruises discussed here. Hooff and Peterson (2006) found that the copepod community and some representative species responded to changes in the sign of the PDO in a predictable manner. That is, when the PDO was in negative phase, the copepod community sampled in shelf waters was composed of northern or 'cold water' species that are resident in the Bering Sea and coastal Gulf of Alaska: Calanus marshallae, Pseudocalanus mimus, and Acartia longiremis. When the PDO was in positive phase, the copepod community was composed of southern or 'warm-water' species such as Calanus pacificus, Paracalanus parvus, Ctenocalanus vanus, and several species of Clausocalanus. Changes in the 
copepod community lagged changes in the PDO by 3-5 months. They concluded that changes in source waters which feed the California Current, driven by remote basin scale forcing, and not local environmental events caused interannual-to-decadal variations in copepod community species composition in waters off Oregon. Therefore, the copepod communities which occur off Oregon, being wholly planktonic, reflect the origin of the water masses which feed the California Current. The observation that the most abundant fish larvae did not respond in such a clear manner as the copepods should not be surprising given that the adults are not planktonic, and the most common taxa in our study are largely non-migratory. Compared to the copepods, the fish taxa we sampled exhibit a broader range of spawning times, egg and larval duration, and spawning habitats, and thus are subject to a greater range of variability in ocean conditions during the critical recruitment periods for each species. Thus, the presence-absence or abundance of their larvae in the water column is likely to be influenced by local productivity or local predation events in addition to the different origins of the source waters which feed the NCC.

Although we were able to show that at least one of our examined variables was significantly related to each of the dominant larval taxa, in some cases the explanatory power was quite low, indicating that other, perhaps more complex, factor(s) not directly measured may be responsible for the abundance patterns we observed. As our sampling occurred at two fixed stations, we could not examine whether alongshore shifts in the centers of distribution of our species have occurred, as seen for larvae of oceanic fishes off California (Hsieh et al., 2009), which may appear in our data as seasonal or interannual variability and obscure any simple relationships with environmental variables. We also were not specifically able to examine biological mechanisms such as starvation and predation (Bakun and Broad, 2003; Agostini et al., 2007) that may be directly related to survival, although some of the physical variables may serve as a proxy for these biological effects. However, our results have shown that several routinely measured and easily available climate and oceanographic indices are coherent with variations in larval abundance and diversity, and that they may ultimately allow prediction of future trends in fish recruitment and production.

\section{ACKNOWLEDGEMENTS}

We thank the captains, crews, and participating scientists of the many ships employed to collect the data used in this study, and all those who helped in the sorting and identification of the ichthyoplankton samples and with data analysis. We particularly thank S. Remple for helping with our database development. We thank R. Hooff, L. Weitkamp, E. Casillas, and two anonymous reviewers for critical reviews of the manuscript. Funding was provided by NOAA's Stock Assessment Improvement Program (SAIP), Fisheries and the Environment Initiative (FATE), Northeast Pacific GLOBEC Program, and Oregon Sea Grant.

\section{REFERENCES}

Agostini, V.N., Bakun, A. and Francis, R.C. (2007) Larval stage controls on Pacific sardine recruitment variability: high zooplankton abundance linked to poor reproductive success. Mar. Ecol. Prog. Ser. 345:237-244.

Ahlstrom, E.H. (1966) Distribution and abundance of sardine and anchovy larvae in the California Current region off California and Baja California, 1951-65: a summary. US Fish Wildl. Serv. Spec. Sci. Rep. Fish. 534:1-71.

Auth, T.D. (2008) Distribution and community structure of ichthyoplankton from the northern and central California Current in May 2004-06. Fish. Oceanogr. 17:316-331.

Auth, T.D. (2009) Importance of far-offshore sampling in evaluating the ichthyoplankton community in the northern California Current. CalCOFI Rep. 50:107-117.

Auth, T.D. and Brodeur, R.D. (2006) Distribution and community structure of ichthyoplankton off the Oregon coast, USA, in 2000 and 2002. Mar. Ecol. Prog. Ser. 319:199-213.

Auth, T.D., Brodeur, R.D. and Fisher, K.M. (2007) Diel variation in vertical distribution of an offshore ichthyoplankton community off the Oregon coast. Fish. Bull. 105: 313-326.

Bakun, A. and Broad, K. (2003) Environmental loopholes and fish population dynamics: comparative pattern recognition with focus on El Niño effects in the Pacific. Fish. Oceanogr. 12:1-16.

Barth, J.A., Menge, B.A., Lubchenco, J. et al. (2007) Delayed upwelling alters nearshore coastal ocean ecosystems in the northern California Current. Proc. Natl Acad. Sci. USA 104:3719-3724.

Beaugrand, G., Brander, K.M., Lindley, J.A., Souissi, S. and Reid, P.C. (2003) Plankton effect on cod recruitment in the North Sea. Nature 426:661-664.

Boeing, W.J. and Duffy-Anderson, J.T. (2008) Ichthyoplankton dynamics and biodiversity in the Gulf of Alaska: responses to environmental change. Ecol. Indic. 8:292-302.

Bradford, M.J. (1992) Precision of recruitment predictions from early life stages of marine fishes. Fish. Bull. 90:439-453.

Brodeur, R.D., Gadomski, D.M., Pearcy, W.G., Batchelder, H.P. and Miller, C.B. (1985) Abundance and distribution of ichthyoplankton in the upwelling zone off Oregon during anomalous El Niño conditions. Est. Coast. Shelf Sci. 21:365378.

Brodeur, R.D., Fisher, J.P., Morgan, C.A., Emmett, R.L. and Casillas, E. (2005) Species composition and community structure of pelagic nekton off Oregon and Washington under variable oceanographic conditions. Mar. Ecol. Prog. Ser. 298:41-57. 
Brodeur, R.D., Ralston, S., Emmett, R.L., Trudel, M., Auth, T.D. and Phillips, A.J. (2006) Anomalous pelagic nekton abundance, distribution, and apparent recruitment in the northern California Current in 2004 and 2005. Geophys. Res. Lett. 33:L22S08. doi:10.1029/2006GL026614.

Brodeur, R.D., Peterson, W.T., Auth, T.D., Soulen, H.L., Parnel, M.M. and Emerson, A.A. (2008) Abundance and diversity of coastal fish larvae as indicators of recent changes in ocean and climate conditions in the Oregon upwelling zone. Mar. Ecol. Prog. Ser. 366:187-202.

Chan, F., Barth, J.A., Lubchenco, J. et al. (2008) Emergence of anoxia in the California Current large marine ecosystem. Science 319:920.

Doyle, M.J. (1995) The El Niño of 1983 as reflected in the ichthyoplankton off Washington, Oregon, and northern California. Can. Spec. Publ. Fish. Aquat. Sci. 121:161180.

Doyle, M.J., Picquelle, S.J., Mier, K.L., Spillane, M.C. and Bond, N.C. (2009) Larval fish abundance and physical forcing in the Gulf of Alaska, 1981-2003. Prog. Oceanogr. 80:163-187.

Fox, C.J., O'Brien, C.M., Dickey-Collas, M. and Nash, R.D.M. (2000) Patterns in the spawning of cod (Gadus morhua L.), sole (Solea solea L.) and plaice (Pleuronectes platessa L.) in the Irish Sea as determined by generalized additive modeling. Fish. Oceanogr. 9:33-49.

Fuiman, L.A. and Werner, R.G.. (eds) (2002) Fishery Science: The Unique Contributions of Early Life Stages. Oxford: Blackwell Science.

Green, P.J. and Silverman, B.W. (1994) Nonparametric Regression and Generalized Linear Models: A Roughness Penalty Approach. New York, NY: Chapman and Hall.

Hastie, T.J. and Tibshirani, R.J.. (1990) Generalized Additive Models. New York: Chapman and Hall.

Hooff, R.C. and Peterson, W.T. (2006) Copepod biodiversity as an indicator of changes in ocean and climate conditions of the northern California current ecosystem. Limnol. Oceanogr. 51:2607-2620.

Houde, E.D. (1989) Comparative growth, mortality, and energetics of marine fish larvae: temperature and implied latitudinal effects. Fish. Bull. 87:471-495.

Houde, E.D. (1997) Patterns and consequences of selective processes in teleost early life histories. In: Early Life History and Recruitment in Fish Populations. R.C. Chambers \& E.A. Trippel (eds) London: Chapman and Hall, pp. 172-196.

Houde, E.D. (2008) Emerging from Hjort's shadow. J. Northwest Atl. Fish. Sci. 41:53-70.

Hsieh, C., Reiss, C., Watson, W. et al. (2005) A comparison of long-term trends and variability in populations of larvae of exploited and unexploited fishes in the Southern California region: a community approach. Prog. Oceanogr. 67:160-185.

Hsieh, C., Kim, J.J., Watson, W., Di Lorenzo, E. and Sugihara, G. (2009) Climate-driven changes in abundance and distribution of larvae of oceanic fishes in the southern California region. Glob. Change Biol. 15:2137-2152.

Huyer, A., Wheeler, P.A., Strub, P.T., Smith, R.L., Letelier, R. and Kosro, P.M. (2007) The Newport line offOregon-Studies in the Northeast Pacific. Prog. Oceanogr. 75:126-160.

Keller, A.A., Simon, V.H., Chan, F. et al. (2010) Demersal fish and invertebrate biomass in relation to an offshore hypoxic zone along the U.S. West Coast. Fish. Oceanogr. 19:76-87.
Krebs, C.J. (1989) Ecological Methodology. New York: Harper Collins Publishers.

Laidig, T.E., Sakuma, K.M. and Stannard, J.A. (2004) Description and growth of larval and pelagic juvenile pygmy rockfish (Sebastes wilsoni) (family Sebastidae). Fish. Bull. 102:452-463.

Laroche, J.L., Richardson, S.L. and Rosenberg, A.A. (1982) Age and growth of pleuronectid, Parophrys vetulus, during the pelagic larval period in Oregon coastal waters. Fish. Bull. 80:93-104.

Love, M.S., Yoklavich, M. and Thorsteinson, L. (2002) The Rockfishes of the Northeast Pacific. Berkeley: University of California Press.

Matarese, A.C., Kendall, A.W. Jr and Vinter, B.M. (1989) Laboratory guide to early life history stages of northeastern Pacific fishes. NOAA Tech. Rep. NMFS 80:625.

Parnel, M.M., Emmett, R.L. and Brodeur, R.D. (2008) Ichthyoplankton community in the Columbia River plume off Oregon: effects of fluctuating oceanographic conditions. Fish. Bull. 106:161-173.

Parrish, R.H., Nelson, C.S. and Bakun, A. (1981) Transport mechanisms and reproductive success of fishes in the California Current. Biol. Oceanogr. 1:175-203.

Pearcy, W.G. (2002) Marine nekton off Oregon and the 199798 El Niño. Prog. Oceanogr. 54:399-403.

Pearcy, W.G. and Schoener, A. (1987) Changes in the marine biota coincident with the 1982-1983 El Niño in the northeastern subarctic Pacific Ocean. J. Geophys. Res. 92: No. C13, 14417-14428.

Peterson, W.T. and Schwing, F.B. (2003) A new climate regime in northeast Pacific ecosystems. Geophys. Res. Let. 30:1896. doi:10.1029/2003GL017528.

Richardson, S.L. and Pearcy, W.G. (1977) Coastal and oceanic larvae in an area of upwelling off Yaquina Bay, Oregon. Fish. Bull. 75:125-145.

Richardson, S.L., Dunn, J.R. and Naplin, N.A. (1980) Eggs and larvae of butter sole, Isopsetta isolepis (Pleuronectidae), off Oregon and Washington. Fish. Bull. 78:401-417.

Schwing, F.G., Mendelssohn, R., Bograd, S.J., Overland, J.E. and Ito, S. (2010) Climate change, teleconnection patterns, and regional processes forcing marine populations in the Pacific. J. Mar. Syst. 79:245-257.

Shannon, C.E. and Weaver, W. (1949) The Mathematical Theory of Communication. Urbana, IL: University of Illinois Press.

Stenseth, N.C., Ottersen, G., Hurrell, J.W. et al. (2003) Studying climate effects on ecology through the use of climate indices: the North Atlantic Oscillation, El Niño Southern Oscillation and beyond. Proc. R. Sci. B. 270:2087-2096.

Wheeler, P.A., Huyer, A. and Fleischbein, J. (2003) Cold halocline, increased nutrients and higher chlorophyll off Oregon in 2002. Geophys. Res. Lett. 30:15, doi:10.1029/ 2003 GL017395.

Wood, S.N. (2004) Stable and efficient multiple smoothing parameter estimation for generalized additive models. J. Am. Stat. Assoc. 99:637-686.

Wood, S.N.. (2006) Generalized Additive Models: An Introduction with R. New York: Chapman and Hall.

Wood, S.N. and Augustin, N.H. (2002) GAMs with integrated model selection using penalized regression splines and applications to environmental modeling. Ecol. Modell. 157:157-177. 